\title{
光学ガラスの表面に及ぼす希薄 $\mathrm{NaCl}$ 電解還元水の影響*
}

\author{
佐藤運海** 㴰本剛史 ${ }^{* *} \quad$ 池田由佳 ${ }^{\dagger} \quad$ 馬場隆充 $^{\dagger \dagger}$
}

\author{
Influence of Electrolyzed Reducing Water of Dilute $\mathrm{NaCl}$ on the Surface of Optical Glass
}

Unkai SATO, Takafumi TAKIMOTO, Yuka IKEDA and Takamitsu BABA

This paper describes the influence of electrolyzed reducing water of dilute $\mathrm{NaCl}(\mathrm{NaCl} \mathrm{ER}$ water) on the surface of optical glass. First, the etching characteristic of $\mathrm{NaCl} \mathrm{ER}$ water on the surface of optical glass was made clear by the comparative immersion experiments with $\mathrm{NaCl}$ ER water and $\mathrm{NaOH}$ solution. The results show that as for the etching effects on optical glass, $\mathrm{NaCl} \mathrm{ER}$ water is same as the $\mathrm{NaOH}$ solution and becomes weak. Next, the influence of $\mathrm{NaCl} \mathrm{ER}$ water on the surface shape, chemical composition and chemical bonding of the surface of optical glass was made clear, by the observation using the AFM image and the result of ESCA (Electron Spectroscopy for Chemical Analysis). The results indicated that $\mathrm{NaCl} \mathrm{ER}$ water did not have any bad influence on the surface shape, chemical composition and chemical bonding of optical glass. Lastly, by the washing experiment, the efficiency of $\mathrm{NaCl} \mathrm{ER}$ water in abrasives particulate removal is verified.

Key words: optical glass, electrolyzed reducing water, surface shape, chemical composition, chemical bonding, washing

\section{1. 緒言}

光学製品, 電気・電子製品などに使用されている光学ガラス 構成部品の表面平滑度, 清浄度および表面層における化学組成 に対する要求が厳しくなる一方である. そのため, 光学ガラス の研磨および洗浄などの工程において，高価で，環境に悪影響 を与える恐れがある研磨スラリーや洗浄薬液などが多量に使用 されている. 特に, 最近の研磨材 $\left(\mathrm{CeO}_{2}\right.$ など）の価格高騰によ って, 研磨コストが高くなり, 研磨加工に支障をもたらしてい る. 環境負荷の軽減および製造コストの削減という観点から， 研磨スラリーおよび洗浄薬液の使用量の削減に関する研究は必 要不可欠であると言える.

著者らは, 希薄電解水を金属材料および半導体材料の表面加 工および処理に応用する研究を行ってきた. 希薄 $\mathrm{NaCl}$ 電解還 元水は, 切削溶液および洗浄溶液の替りにステンレス鋼などの 金属材料の切削加工 1 ${ }^{3}$ ), 炭素鋼切削面の脱脂洗浄 4)に応用でき, 研磨スラリーおよび洗浄溶液としてシリコンウエハの精密研 磨 5)および研磨材微粒子除去洗浄 6)にも有効である. 電解還元水 は，人体および環境への影響が少なく，使用後，電解酸化水と 混合すれば, $0.01 \mathrm{wt}$ \%程度の $\mathrm{NaCl}$ 溶液となり, 廃棄処理を必 要としないため, 製造コストが低くなる. また, 電解還元水は, 酸化還元電位(ORP: Oxidation Reduction Potential)がマイナ ス側に大きく, 溶存水素濃度が高く, 水素ナノバブルも存在し ている7)。これらの特性は, 研磨スラリー中における研磨材微粒 子の分散, 研磨後のガラス試料片の表面に付着している研磨材 微粒子の除去に有効になると考えられる. そこで, 本研究は, 電解還元水を光学ガラスの研磨および洗浄などの工程に応用す ることを目的として, まず, 電解還元水の光学ガラス表面に対 するエッチング作用, ガラス表面形状および表面層における化 学組成への影響について, 浸漬によるエッチング実験, 表面形

*原稿受付 平成 23 年 7 月 8 日

**正会員信州大学教育学部 (長野市西長野 6 の口)

****学生会員信州大学大学院（長野市西長野 6 の口）

†正会員 (侏ニットー（長野県須坂市大字八重森 2-2)

†十(株)ニットー（長野県須坂市大字八重森 2-2)
状測定，化学組成分析などの実験検討を行った，つぎに洗浄実 験によって, 研磨工程後のガラス表面の研磨材微粒子除去洗浄 における電解還元水の有効性を検証した. 本研究によって, 電 解還元水は, 光学ガラスの表面に悪影響を与えず, 表面洗浄な どの工程に応用できる可能性を得たので報告する.

\section{2. 実験 方 法}

\section{1 電解還元水の生成および実験用光学ガラス試料}

電解質塩はもっとも安価となる $\mathrm{NaCl}$ を使用した. 有害とさ れている塩化物イオン $(\mathrm{Cl})$ )゙含まないように, 三槽式の電解水 生成装置 7を使用することにした. 電解電流值を $15 \mathrm{~A}$ に, 電解還 元水および電解酸化水の流量をともに約 $2 \mathrm{~L} / \mathrm{min}$ に設定し, 電 解還元水を生成した. 表 1 に生成直後の $\mathrm{NaCl}$ 電解還元水, お よびその $\mathrm{pH}$ 值に合わせて作製した $\mathrm{NaOH}$ 溶液の特性值を示し ている. 表中の ER water(Electrolyzed Reducing water), EC(Electrical Conductivity), DH(Dissolution Hydrogen)およ

Table 1 Characteristics of $\mathrm{NaCl}$ ER water and $\mathrm{NaOH}$ solution

\begin{tabular}{l|l|l}
\hline & $\mathrm{NaCl}$ ER water & $\mathrm{NaOH}$ solution \\
\hline $\mathrm{pH}$ & 12.31 & 12.32 \\
\hline ORP $\mathrm{mV}$ vs.Ag/AgCl & -892 & 103 \\
\hline $\mathrm{EC} \mathrm{mS} / \mathrm{m}$ & 252 & 265 \\
\hline $\mathrm{DH} \mathrm{ppm}$ & 0.72 & 0.00 \\
\hline DO $\mathrm{ppm}$ & 2.28 & 8.84 \\
\hline
\end{tabular}

Table 2 Chemical composition of optical glass test pieces

\begin{tabular}{l|c|c}
\hline \multirow{2}{*}{} & \multicolumn{2}{|c}{ Composition wt\% } \\
\cline { 2 - 3 } & A type & B type \\
\hline $\mathrm{SiO}_{2}$ & 81 & $55 \sim 65$ \\
\hline $\mathrm{B}_{2} \mathrm{O}_{3}$ & 13 & $8 \sim 13$ \\
\hline $\mathrm{Al}_{2} \mathrm{O}_{3}$ & 2 & $13 \sim 18$ \\
\hline $\mathrm{Na}_{2} \mathrm{O} \& \mathrm{~K}_{2} \mathrm{O}$ & 4 & 0 \\
\hline $\mathrm{BaO}, \mathrm{CaO}, \mathrm{SrO} \& \mathrm{ZnO}$ & 0 & $10 \sim 25$ \\
\hline
\end{tabular}


びDO(Dissolved Oxygen)はそれぞれ電解還元水, 電気伝導率, 溶存水素および溶存酸素の略称である. 同 $\mathrm{pH}$ 值の $\mathrm{NaOH}$ 溶液 と比べ, ORP 值がマイナス側に大きく, 溶存水素濃度が高く, 溶存酸素濃度が低くなっているのは電解還元水の特徵であると 言える.

光学ガラス試料片は $\mathrm{A}$ と B の 2 タイプのものを使用し, その 化学組成を表 2 に示寸. 試料片は大きさが $50 \mathrm{~mm} \times 50 \mathrm{~mm}$, 厚 さが約 $0.7 \mathrm{~mm}$ となる. 試料片の表面状態は, 購入した素材のま まのものと, 表面に研磨加工を施したものとの 2 種類を使用し た.

\section{2 光学ガラスに対する電解還元水のエッチング作用}

光学ガラスの表面に対寸る電解還元水のエッチング作用を明 らかにするために, 表 1 に示している電解還元水および $\mathrm{NaOH}$ 溶液に試料片を浸漬する実験を行った. 各種溶液 $200 \mathrm{~mL}$ に試 料片を 1 枚 10 時間浸漬し, 1 時間ごとに試料片の重さを分解能 が $0.1 \mathrm{mg}$ の電子天秤（島津製作所, AUW220）によって測定し た．その際，試料片を純水でリンスし，アセトンによる置換処 理を行ったあと, ドライヤで乾燥した. なお, 浸漬溶液の温度 は約 $20^{\circ} \mathrm{C}$ である. 以降の実験も同様の溶液温度で行った.

\section{3 光学ガラスの表面形状および化学組成への影響}

電解還元水が光学ガラスの表面形状および表面層における化 学組成に与える影響を明らかにするために, ガラス試料片を表 1 に示している電解還元水および $\mathrm{NaOH}$ 溶液に 100 分浸漬し, 表 面形状および表面層における化学組成を評価することにした。 浸漬処理時, 各種溶液の量は 2.2 のエッチング性能実験と同様 に $200 \mathrm{~mL}$ に設定した．表面形状に与える影響の解明に関する 実験では, 表面の平滑度が高い研磨工程後のものを使用した。 これに対して, 表面層の化学組成に与える影響の解明実験では, 購入した素材のままのものを使用した. なお, 試料片は, 各種 溶液に浸漬したあと, 純水で 1 分間程度のリンスをして, アセ トンによる置換処理を行い, ドライヤで乾燥した.

光学ガラスの表面形状に及ぼす電解還元水の影響を明らかに するために，浸漬処理を行ったあとの試料片および浸漬処理を 行っていない試料片の表面形状について, AFM(Digital Instruments 社, D3100HP-2 NS3A)を用いて測定をし, 比較お よび評価を行った.

電解還元水が光学ガラスの表面層における化学組成への影響 を明らかにするために, 電解還元水および $\mathrm{NaOH}$ 溶液に 100 分 浸漬した試料片，および浸漬処理を行っていない試料片の表面 について, ESCA (Electron Spectroscopy for Chemical Analysis, 島津製作所/Kratos 社製, AXIS HS3.5）分析を行っ た. 分析領域は約 $300 \mu \mathrm{m} \times 700 \mu \mathrm{m}$ となっている. なお, ESCA 分析は, $\mathrm{A}$ タイプの試料片のみについて行った.

\section{4 研磨工程後のガラス試料片の表面洗浄}

研磨工程後, ガラス表面に付着している研磨材微粒子除去洗 浄を行う必要がある. 研磨材微粒子の除去洗浄は, 一般的に研 磨工程の直後で行うものであるが, 製造プロセス上の都合で研 磨後のガラス試料片を純水などの溶液に一定時間保管してから 行う場合もある. この場合の研磨材微粒子の除去は, 研磨工程 の直後と比心難しくなる. 本研究では, 電解還元水を直接洗浄 溶液として使用するまえに, 研磨後のガラス試料片を電解還元 水に保管した場合の研磨材微粒子の除去に効果の有無を確認寸 ることにした. 1 時間の研磨加工を行った試料片を表 1 に示し ている電解還元水, $\mathrm{NaOH}$ 溶液および純水(電気伝導率が約 $0.03 \mathrm{mS} / \mathrm{m}$ )に 24 時間浸漬してから, 現状の洗浄工程と同様に超
音波を併用し, 純水で 1 分間の洗浄を行った. 超音波洗浄器 (侏) エスエネディ, US-1K）の周波数は $38 \mathrm{kHz}$ である. 試料片の 24 時間浸漬用の各種溶液の温度は $20^{\circ} \mathrm{C}$ であり, 超音波洗浄を行 うとき, 洗浄溶液である純水の温度を $20^{\circ} \mathrm{C}, 40^{\circ} \mathrm{Cおよび} 60^{\circ} \mathrm{C}$ の 3 種類に設定した. また, 洗浄実験用の試料片を研磨すると き, 研磨スラリーは洗浄工程において最も除去されにくいコロ イダルシリカ $\left(\mathrm{SiO}_{2}\right)$ （侏)フジミインコーポレーテッド, COMPOL-80）を使用した。

洗浄後の試料片表面の清浄度については, 八ロゲン光源と集 光レンズ付きの光ファイバー照明を用いて目視観察を行った.

\section{3. 実験結果および考察}

\section{1 浸漬によるエッチング実験}

電解還元水および $\mathrm{NaOH}$ 溶液に $\mathrm{A}$ タイプの試料片を 10 時間 浸漬したエッチング実験結果を図 1 に示す. B タイプは A タイ プと比べ，エッチング量がわずかながら大きくなっているが, 浸漬溶液の種類による相違は $\mathrm{A}$ タイプと同様な傾向になってい るので, 図示を省略する. 浸漬による試料片の重さ減少量から 求めた平均的なエッチング深さも同図に示している. なお，工 ッチング深さは, ガラス試料片の両面からエッチングが進行す ると考えた場合の片面に対する值である.この実験結果から， 光学ガラスの表面に対する電解還元水のエッチング作用は, 現 状の製造工程に使用している $\mathrm{NaOH}$ 溶液と同様のレベルである と言える. また, 浸漬前の試料片の重さが $4.3667 \mathrm{~g}$ に対して, 電解還元水一の 10 時間浸漬による重さ減少量が $0.0001 \mathrm{~g}$ となっ ているため, 電解還元水が光学ガラス表面に対するエッチング 作用は微弱的であると言える. 10 時間の浸漬によるエッチング 深さが $20 \mathrm{~nm}$ 未満となっていることからも同様なことが言える. これは, 電解還元水は, ガラスの主成分である $\mathrm{SiO}_{2}{ }^{6}$ に対寸る エッチング作用が小さいためと考えている.

\section{2 光学ガラスの表面形状への影響}

浸漬処理を行っていない試料片, 電解還元水および $\mathrm{NaOH}$ 溶 液に 100 分浸漬した試料片について, AFM による表面形状の測 定結果を図 2 に示す. また, 同図は, もっとも平滑に研磨され た B タイプの試料片の測定結果であり, タイプ A の試料につい て同様の傾向になっているので図示を省略する. この実験結果 からつぎのことが言える.

表面粗さ Rms については，どちらの試料片も $0.2 \sim 0.3 \mathrm{~nm}$ で 同様のレベルになっている. これに対して, 最大高さ $R \max に$ ついては, 同図 (a)の未浸漬の試料片と比べ, 同図 (b) の電解還 元水に浸漬したものは小さく, 同図 (c) の $\mathrm{NaOH}$ 溶液に浸漬し

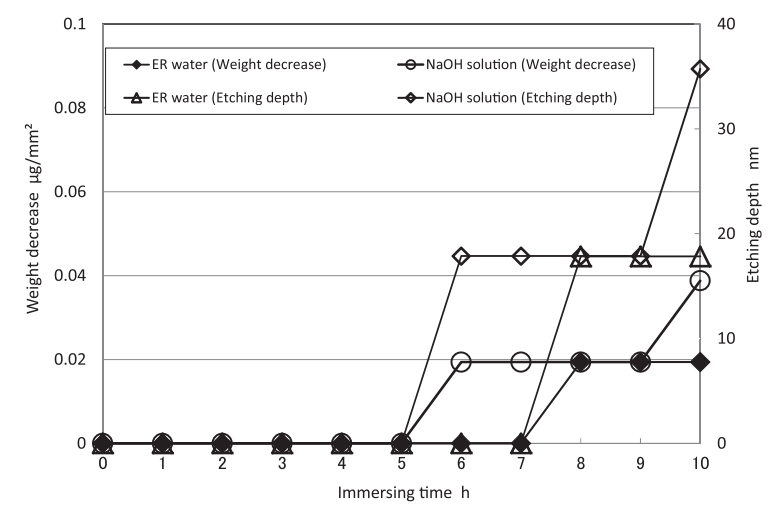

Fig.1 The relation between immersing time and weight decrease (Immersing temperature is $20^{\circ} \mathrm{C}$ ) 


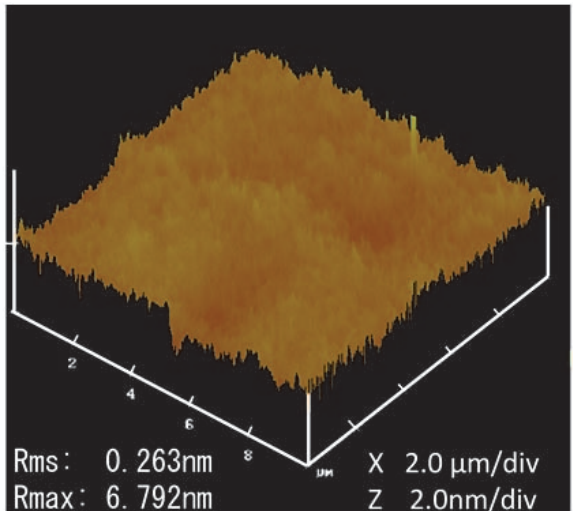

(a) Non-immersed

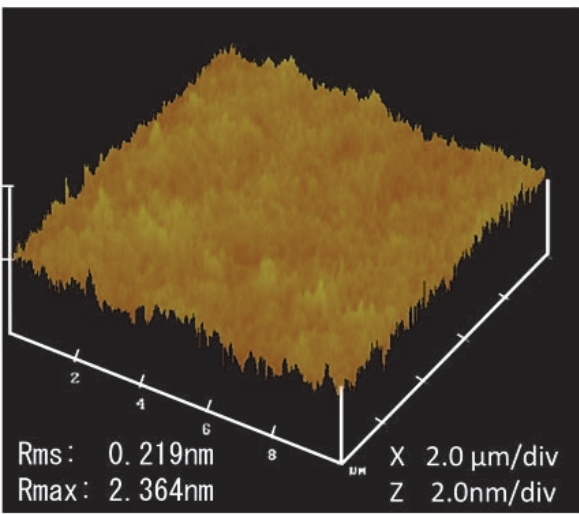

(b) Immersed into ER water for 100 minutes

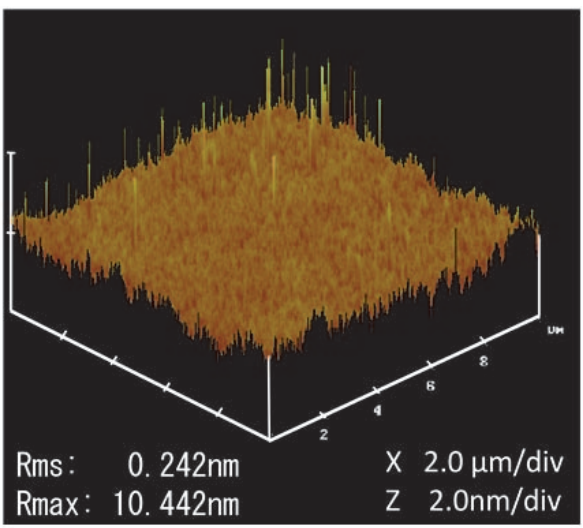

(c) Immersed into $\mathrm{NaOH}$ solution for 100 minute

Fig.2 AFM image of the surface of test pieces (B type)

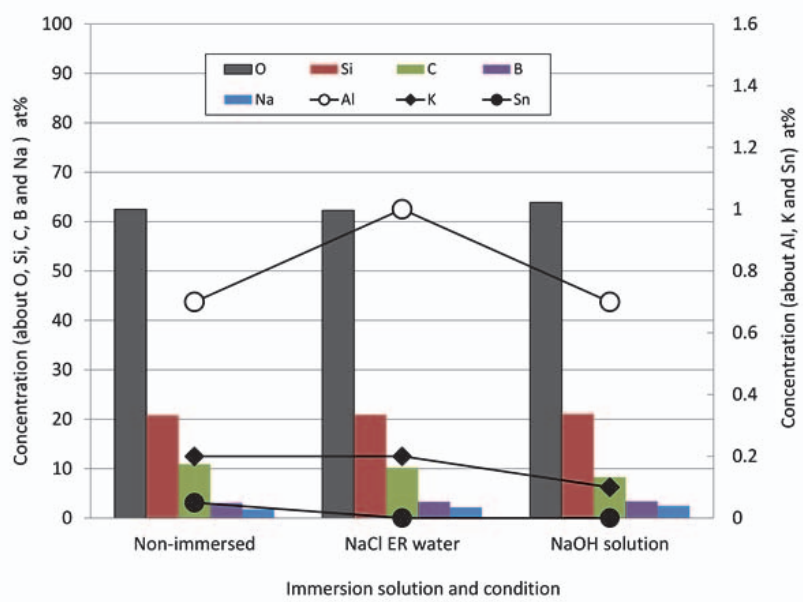

Fig.3 Change of chemical composition about surface layer by the immersion
た試料片は大きくなっている. これは AFM のイメージ画像と も一致している。

電解還元水への浸漬による $\mathrm{Rmax}$ 值が小さくなっているのは, 浸漬によって，試料片表面に付着していた異物が除去されたた め, また $\mathrm{NaOH}$ 溶液への浸漬による $\mathrm{Rmax}$ 值が大きくなってい るのは，新たな異物が付着したためと考えている．電解還元水 と $\mathrm{NaOH}$ 溶液は同じアルカリ性であるが, 酸化還元電位, 溶存 水素濃度および溶存酸素濃度が異なっている. 電解還元水は, $\mathrm{NaOH}$ 溶液と比べ, 溶存水素濃度が高く, 溶存酸素濃度が低い. 溶存水素および溶存酸素の作用，さらにその両者の総合作用を 反映している酸化還元電位の働きによって, 電解還元水に浸漬 すれば，異物および研磨材微粒子を除去しやすく，再付着しに くくなると思われるが, 詳細なメカニズムの解明について今後 の検討課題とする.

\section{3 光学ガラスの表面層における化学組成への影響 \\ 3.3 .1 表面層の化学組成}

ESCA 分析のナロースキャンスペクトルに基づき, 算出した 各試料片の表面層における化学組成は図 3 に示す.この分析結 果からつぎのことが言える. 浸漬処理を行っていない試料片と 比べ, 電解還元水および $\mathrm{NaOH}$ 溶液に 100 分浸漬した試料片に ついて，試料片の主成分である $\mathrm{O}, \mathrm{Si}, \mathrm{B}, \mathrm{Na}$ および，污染が 原因であると推測される $\mathrm{C}$ の濃度は同様であり，含有量の少な い $\mathrm{Al}$ と $\mathrm{K}$ においてはわずかながら差異がある. Sn は試料片の 組成成分ではなく，ガラスの製造工程による污染と考えている. また, 本分析により得られた試料片の主な成分元素の比率は表 2 に示しているものとほぼ一致している。このことから, 電解還 元水は, 光学ガラスの表面層における化学組成に大きな影響を 与えないと判断した.

3.3 .2 表面層における化学結合状態

試料片の主な構成成分である $\mathrm{Si}, \mathrm{B}, \mathrm{Na}$ および $\mathrm{Al}$ に関する ESCAのナロースキャンスペクトルを図4 に示す. 同図(a), (b) , (c) および (d) はそれぞれ $\mathrm{Si}, \mathrm{B}, \mathrm{Na}$ および $\mathrm{Al}$ に関するもので ある.この主な組成元素の化学結合状態の分析結果から, 電解 還元水は現状の製造工程に使用されている $\mathrm{NaOH}$ 溶液と同様に, 浸漬処理によってガラス試料片の表面層における主な元素の化 学結合状態に影響を与えないと言える. すなわち, 電解還元水 および $\mathrm{NaOH}$ 溶液に 100 分浸漬しても，主な構成元素である $\mathrm{Si} ， \mathrm{~B}, \mathrm{Na}$ および $\mathrm{Al}$ の化学結合状態はそれぞれ $\mathrm{SiO}_{2}, \mathrm{~B}_{2} \mathrm{O}_{3}$, $\mathrm{Na}_{2} \mathrm{O}$ および $\mathrm{Al}_{2} \mathrm{O}_{3}$ となり, 未浸漬処理の試料片と全く同様にな っている.この実験結果により, 電解還元水および $\mathrm{NaOH}$ 溶液 のようなアルカリ性溶液は, $\mathrm{Si}, \mathrm{B}, \mathrm{Na}$ および $\mathrm{Al}$ に対してエ ッチング作用があり ${ }^{8}$, 長時間で浸漬するとこれらの元素の化学 結合状態に影響を与える恐れがあるが，室温においては $\mathrm{SiO}_{2}$, $\mathrm{B}_{2} \mathrm{O}_{3}, \quad \mathrm{Na} 2 \mathrm{O}$ および $\mathrm{Al}_{2} \mathrm{O}_{3}$ のような化合物に影響を与えないこ とが明らかとされた。

試料片表面層における $\mathrm{O}$ の化学結合状態について, ナロース キャンスペクトルにより電解還元水および $\mathrm{NaOH}$ 溶液に浸漬し た試料は，未浸漬処理の試料と全く同様になっているので，分 析結果の困示を省略する。

外気などの環境から試料片表面に付着したと思われる $\mathrm{C}$ およ びSnのナロースキャンスペクトルを図 5 に示す. 同図 (a), (b) はそれぞれ C と Sn に関するものである，K のナロースキャン スペクトル， $\mathrm{Na}$ のサブピークの部分もそれぞれ同図(a), (b)に 示している.この分析結果からつぎのことが言える. まず, C の主な化学結合状態について, 電化還元水および $\mathrm{NaOH}$ 溶液に 


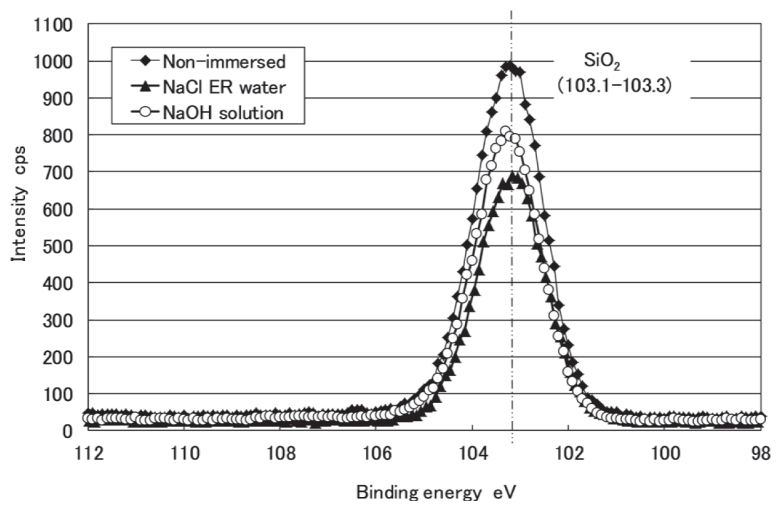

(a) $\mathrm{Si} 2 \mathrm{p}$

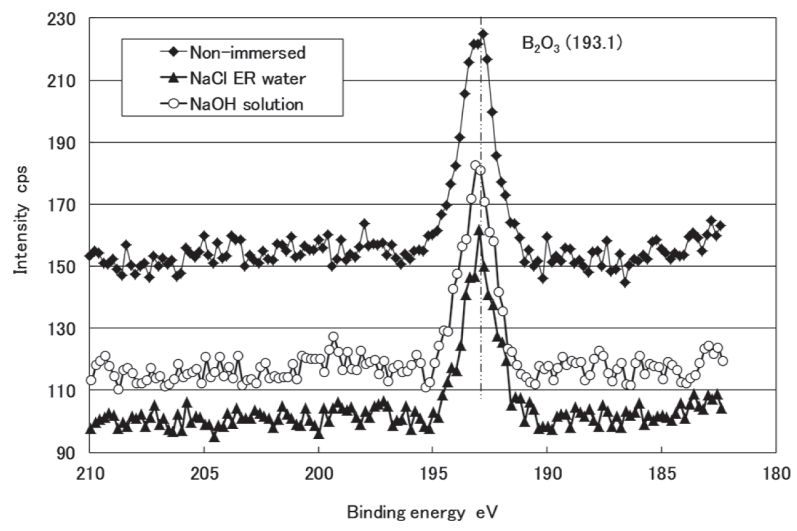

(b) B1s

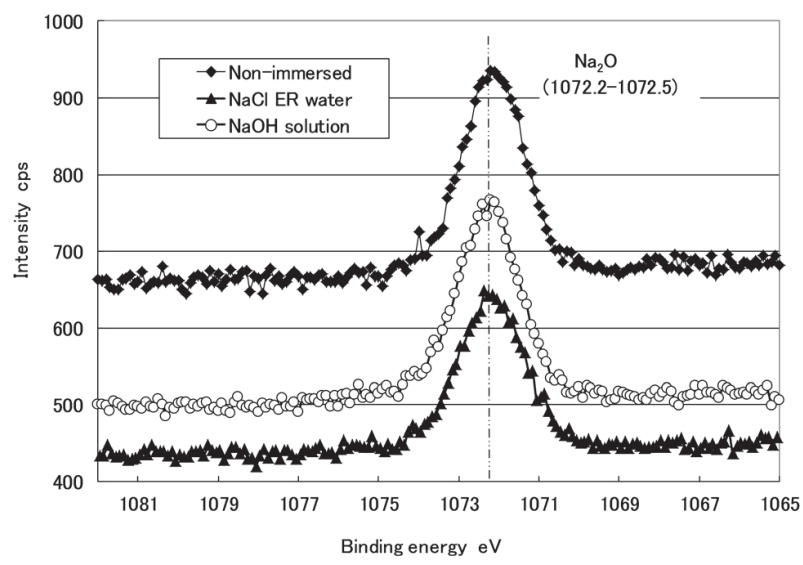

(c) Na1s

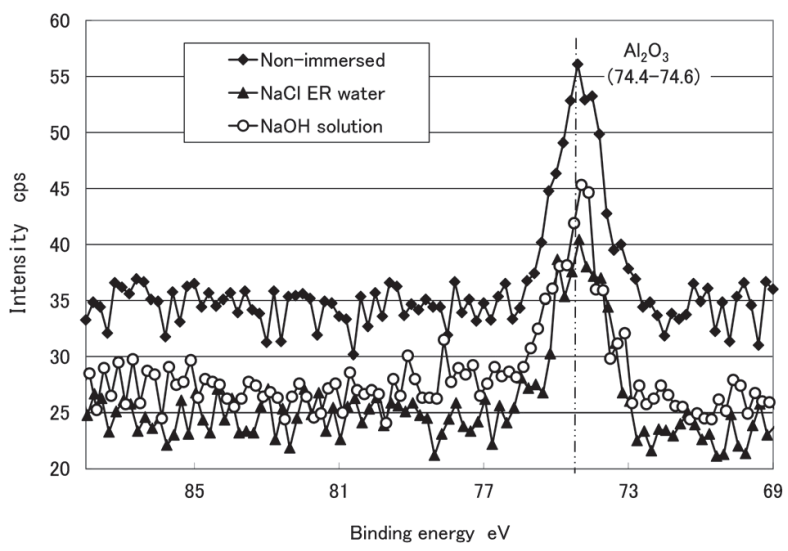

(d) $\mathrm{Al} 2 \mathrm{p}$

Fig.4 Narrow scanned-spectrum of ESCA about main elements

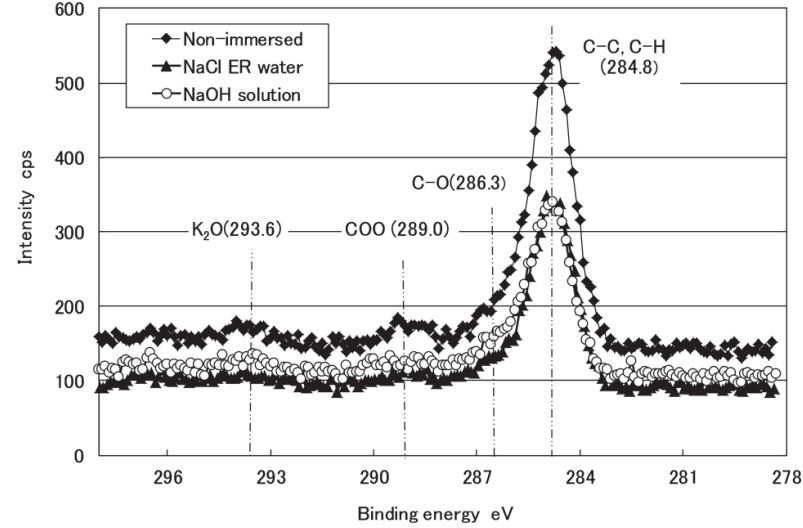

(a) $\mathrm{C} 1 \mathrm{~s}$ and $\mathrm{K} 2 \mathrm{p}$

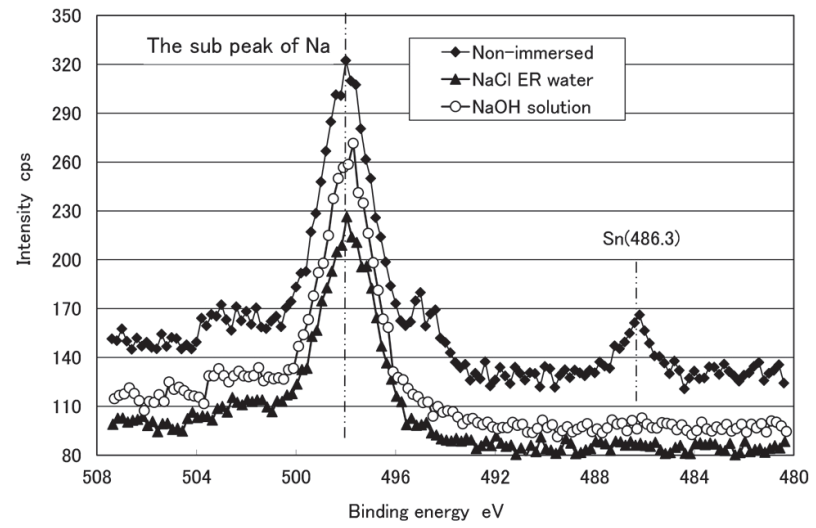

(b) Sn3d

Fig.5 ESCA result about pollution elements

浸漬した試料は，未浸漬処理のものと同様に，C-C，C-H，いわ ゆる有機物結合となっている.このほかに強度が微弱であるが, $\mathrm{C}-\mathrm{O}, \mathrm{COO}$, 寸なわち $\mathrm{CO}, \mathrm{CO}_{2}$ も存在している.このことから， 試料片表面に付着している $\mathrm{C}$ は主に有機物による污染と判断し た. また, 3.3 .1 からも, 電解還元水および $\mathrm{NaOH}$ 溶液への浸 漬により，C 污染量に大きな影響を与えないと判断できる。つ ぎに Sn について, 未浸漬処理の試料に関するナロースキャンス ペクトルにおいて，Snの結合エネルギーとなる $486.3 \mathrm{eV}$ の近 辺にピークが存在している. これに対して, 電解還元水および $\mathrm{NaOH}$ 溶液に浸漬した試料片のナロースキャンスペクトルには $\mathrm{Sn}$ の結合エネルギーを示寸ピークが存在しない. 寸なわち, 電 解還元水および $\mathrm{NaOH}$ 溶液への浸漬により, 試料片の構成成分 ではなく,ガラスの製造工程から付着したと思われる Sn が除去 されたと考えられる. 一般的に，ガラス板はフロート法により 製造され，才なわちガラス融夜を溶融錫の上に流れ出すことで, ガラス板を形成している. Sn の付着はこの工程において発生し たと思われる。

$\mathrm{K}$ および $\mathrm{Na}$ のサブピークの部分においても, 電解還元水お よび $\mathrm{NaOH}$ 溶液に浸漬した試料は, 未浸漬処理のものと同様に なっているので, これらの溶液への浸漬により光学ガラス表面 層における化学組成に悪影響を与えないと判断した.

\section{4 電解還元水による表面洗浄の効果}

表 1 に示している電解還元水, $\mathrm{NaOH}$ 溶液および純水に 24 時間浸漬してから，超音波を併用して純水により洗浄を行った A タイプの試料片表面に関寸る観察結果を図 6 に示寸. B タイ プは同様な傾向になっているので図示を省略する，同(a)，(b) および (c) はそれぞれ電解還元水, $\mathrm{NaOH}$ 溶液および純水に 24 


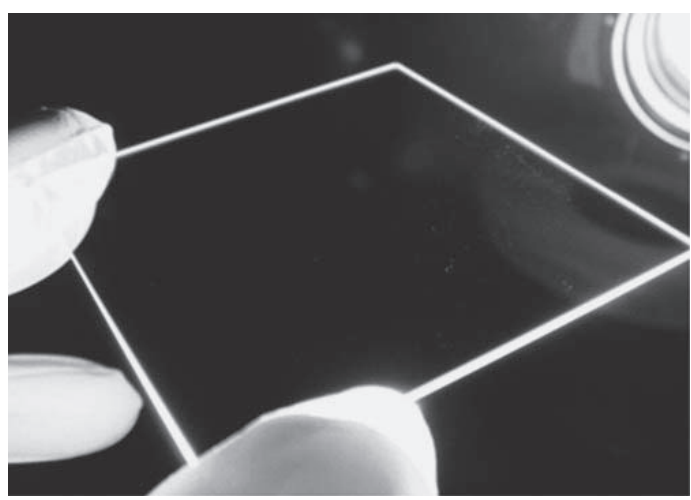

(a) $\mathrm{NaCl}$ ER water

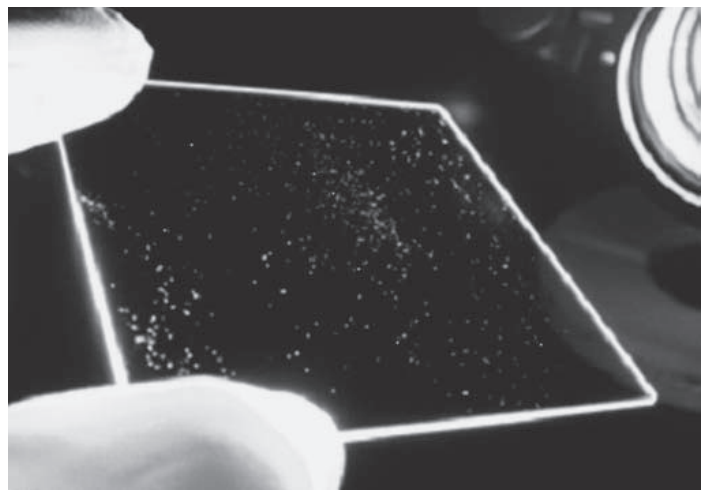

(b) $\mathrm{NaOH}$ solution

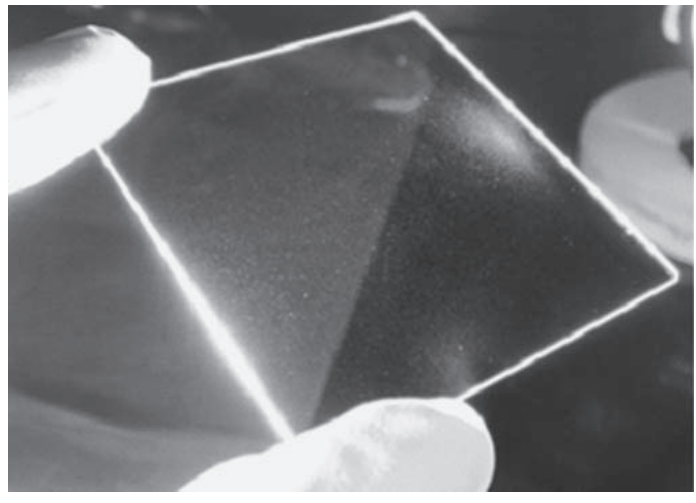

(c) Pure water

Fig.6 The outward appearance of the test pieces surface after wash (Before wash, immersed into each solution for 24 hours)

時間浸漬したあと，洗浄を行ったものである．また，同図は洗 浄温度が $40^{\circ} \mathrm{C}$ ものであり, $20^{\circ} \mathrm{Cおよび} 60^{\circ} \mathrm{C}$ ものは同様に もなっているので省略する.

この実験結果から, 試料片の表面清浄度について, 電解還元 水に浸漬した場合はもっとも高く, そのつぎは純水に浸漬した ものであり, もっとも低くなっているのは $\mathrm{NaOH}$ 溶液に浸漬し たものであると確認できる. このことから, 研磨後の試料片を 電解還元水に浸漬した場合, 洗浄工程において研磨材微粒子が 除去されやすくなると同時に, 研磨面に研磨材微粒子などが再 付着されにくくなったと推測される.

純水および $\mathrm{NaOH}$ 溶液と比べ, 電解還元水に浸漬した場合, 洗浄後の試料片表面の清浄度が高くなっているのは, 電解還元 水のアルカリ性, 高溶存水素濃度, 低溶存酸素濃度などの特性 に起因していると考えられる. まず，アルカリ性の溶液におい ては, ガラス研磨面および研磨材微粒子の表面のどちらにおい てもマイナスゼータ電位になり, 電気的な反発力によって微粒
子を研磨面から引き離すことができる. また, 同様の理由で, 研磨材微粒子がアルカリ性溶液中に均一に分散され, 研磨面一 の再付着量が少なくなる.これは, $\mathrm{NaOH}$ 溶液においても同様 である。つぎに, 溶存酸素濃度が低く, 溶存水素濃度が高くな ると, 活性になっているガラス研磨面において, 水素原子ある いは分子の還元作用, さらに水素終端化作用 9)により表面が不活 性になり, 異物との化学反応が発生しにくく, 異物の付着もし にくくなる可能性がある. これは電解還元水が $\mathrm{NaOH}$ 溶液と異 なっているところである. $\mathrm{NaOH}$ 溶液に浸漬した場合, 洗浄後 の試料片表面に残っている異物は, 溶液中の $\mathrm{Na}^{+}$や研磨材微粒 子などが活性となっている研磨面との化学反応物であると推測 されるが，詳細について今後表面分析などにより解明していく 予定である.

このことから, 電解還元水を研磨後のガラス表面洗浄に応用 する場合, 純水および $\mathrm{NaOH}$ 溶液と比べ洗浄効果が期待できる と考えられ, 環境に優しい, 洗浄効果が期待できる光学ガラス の表面洗浄方法を開発するための示唆を得た. 今後, 電解還元 水を光学ガラス研磨および洗浄工程に応用するために, 引き続 き検討していく予定である.

\section{4. 結言}

以上の検討によって，以下のことを明らかにした。

(1) 希薄 $\mathrm{NaCl}$ 電解還元水は, 化学薬液 $\mathrm{NaOH}$ と同様に光学 ガラスの表面に対するエッチング作用が微弱的である.

（2）電解還元水は光学ガラスの表面形状に悪影響を与えない. また, $\mathrm{NaOH}$ 溶液と比べ, 電解還元水への浸漬処理によ り, 異物が光学ガラスの表面に付着しにくくなる.

（3）電解還元水は, 光学ガラスの表面層における化学組成, 構 成元素の化学結合状態に影響を与えない.

（4）純水および $\mathrm{NaOH}$ 溶液と比べ, 電解還元水に浸漬した場 合, 洗浄後のガラス表面における清浄度が高い.

\section{謝辞}

本研究の一部は日本学術振興会科学研究費補助金（基盤研究 (C), 課題番号 22560717 平成 23 年度) を得て行われたもので あることを付記し，ここに深く謝意を表す。また，卒論学生小 池沙知，小川彩，北川大貴諸君に感謝の意を表す。

\section{参 考文 献}

1）佐藤運海, 竹ノ内敏一, 原 宏, 山崎隆夫, 若林信一: 電解還元水を 用いた炭素鋼のエンドミル加工，日本機械学会論文集 $\mathrm{C}$ 編, 71,710 (2005) 3074.

2) 佐藤運海, 竹八内敏一, 原 宏, 山崎隆夫, 若林信一: 電解還元水を 用いたステンレス鋼のエンドミル加工, 日本機械学会論文集 C 編, 72,718（2006） 1987.

3）佐藤運海, 竹ノ内敏一, 原 宏, 若林信一: 電解還元水を用いたアル ミニウム合金のエンドミル加工，日本機械学会論文集 C 編, 72,722 (2006) 3398.

4) 佐藤運海, 竹八内敏一, 田中博志, 山崎隆夫, 若林信一, 佐藤元太郎 : 電解還元水を用いた炭素鋼切削面の脱脂洗浄, 精密工学会誌, 70,2(2004)281.

5) 佐藤運海, 市川浩一郎 : 希薄 $\mathrm{NaCl}$ 電解還元水を用いたシリコンウエ 八の精密研磨，精密工学会誌，72,10(2006)1247.

6) 佐藤運海, 竹ノ内敏一, 若林信一, 佐藤元太郎 : 電解水を用いたシリ コンウエハの超精密洗浄, 精密工学会誌, 71,6(2005)756.

7) 佐藤運海, 竹/内敏一, 山崎隆夫 : 希薄 $\mathrm{NaCl}$ 電解水の基本特性の解 明, 精密工学会誌, 75,7(2009)902.

8) M.Pourbaix: atlas of Electrochemical Equilibria in Aqueous Solution, NACE Intemational Cebelcor(1974) 459.

9）都田昌之: 初歩から学ぶ機能水 目的に合った水を作る，日本産業洗 浄協会 (2004) 134. 